FRANGIS BACON 


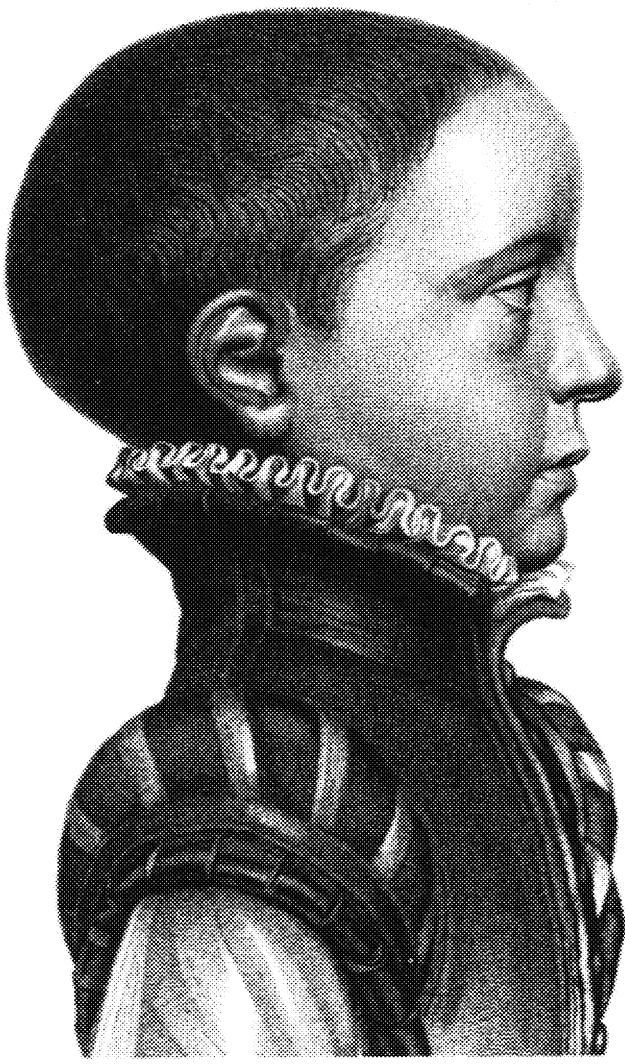

Francis Bacon as a boy. Nineteenth-century engraving of a bust of Bacon made around 1572 


\title{
Francis Bacon
}

$\approx$

\author{
By Perez Zagorin
}

PRINCETON

U N I V E R S I T Y

P R E S S 
Copyright $\odot 1998$ by Princeton University Press Published by Princeton University Press, 41 William Street, Princeton, New Jersey 08540

In the United Kingdom: Princeton University Press, Chichester, West Sussex

All Rights Reserved

Third printing, and first paperback printing, 1999 Paperback ISBN 0-691-00966-X

The Library of Congress has cataloged the cloth edition of this book as follows Zagorin, Perez.

Francis Bacon / Perez Zagorin.

p. $\mathrm{cm}$.

Includes bibliographical references and index.

ISBN 0-691-05928-4 (alk. paper)

1. Bacon, Francis, 1561-1626. 2. PhilosophersGreat Britain-Biography. I. Title.

$$
\begin{array}{cc}
\text { B1197.Z34 } & 1998 \\
192-d c 21 & 97-41404
\end{array}
$$

This book has been composed in Baskerville

The paper used in this publication meets the minimum requirements of ANSI/NISO Z39.48-1992 (R1997)

(Permanence of Paper)

http://pup.princeton.edu

Printed in the United States of America 
For man is but the servant and interpreter of nature: what he does and what he knows is only what he has observed of nature's order in fact or in thought; beyond this he knows nothing and can do nothing. For the chain of causes cannot by any force be loosed or broken, nor can nature be conquered except by being obeyed.

\section{-Francis Bacon, The Great Instauration}

The human understanding is no dry light, but receives an infusion from the will and affections; whence proceed sciences which may be called "sciences as one would wish." For what a man had rather were true he readily believes.

\section{-Francis Bacon, The New Organon}

... the sovereignty of man lieth hid in knowledge. ...

-Francis Bacon, The Letters and Life of Francis Bacon

I don't follow or share your way of conceiving the historical problem as the determination of a curve by points. I think that that applies only to what is done and over.... But unless the future contains genuine novelties, unless the present is really creative of them, I don't see the use of time at all.

-William James to Henry Adams, 9 February 1908 
